Article

\title{
Seasonal Surface Runoff Characteristics in the Semiarid Region of Western Heilongjiang Province in Northeast China-A Case of the Alun River Basin
}

\author{
Jinbai Huang ${ }^{1, *}$, Kotaro Tagawa ${ }^{2}$, Bin Wang ${ }^{3}$, Jiawei Wen ${ }^{4}$ and Jingcai Wang ${ }^{1}$ \\ 1 School of Hydraulic, Energy and Power Engineering of Yangzhou University, No 196 Huayang -west Road, \\ Yangzhou 225127, Jiangsu Province, China; wanguufly@163.com \\ 2 Faculty of Agriculture, Tottori University, No 4-101Koyama-minami, Tottori 680-8553, Japan; \\ tagawa@tottori-u.ac.jp \\ 3 School of Water Conservancy and Civil Engineering of Northeast Agricultural University, \\ No 600 Changjiang Road, Harbin 150030, Heilongjiang Province, China; wangbin@neau.edu.cn \\ 4 School of Information Engineering of Yangzhou University, No 196 Huayang-west Road, \\ Yangzhou 225127, Jiangsu Province, China; wenjiawei@aliyun.com \\ * Correspondence: huangjinbai@aliyun.com; Tel.: +86-0514-87971315
}

Received: 15 February 2019; Accepted: 14 March 2019; Published: 18 March 2019

check for updates

\begin{abstract}
Water resource issues are a challenging area of research in semiarid regions of the world. The objective of the current study was to reveal the main characteristics of seasonal surface runoff for the semiarid western Heilongjiang Province of China. The Alun River Basin, which has hydrological and meteorological characteristics of the local region, was adopted as the study location. A distributed rainfall-runoff combined with snowmelt hydrological model was used to carry out the runoff calculation for the six years (2011-2016). The results indicated that: The mean annual runoff coefficient was 0.34 ; snowmelt runoff accounted for 2.2\% of annual total runoff in 2011-2016; the main part of annual rainfall and runoff was concentrated in the rainy season from June to September, the proportions of rainfall and runoff in this period were $78 \%$ and $86 \%$ to that of the annual means of 2011-2016; the peak flow represents a decreased trend since 2013, and evidently decreased in 2015 and 2016; less annual precipitation complex with paddy field retention of rainwater and runoff led to the peak flow and annual runoff coefficient in 2016 were obviously lower than that of annual means of 2011-2016. The results are expected to provide the basis for rational development and utilization of surface runoff, and further researches on surface runoff and water resources of the semiarid western Heilongjiang Province of China.
\end{abstract}

Keywords: surface runoff; semiarid region; the Alun River Basin; snowmelt; distributed hydrological model

\section{Introduction}

Water resource issues are a challenging area of research in arid and semiarid regions of the world [1]. Semiarid regions are characterized by water scarcity, high-intensity and low-frequency rainfall, as well as runoff generation uncertainties [2]. The stability of agro-ecosystems in semiarid areas strongly depends on the highly effective use of precipitation and other water resources [3]. Crop production in semiarid environments depends heavily on the spatiotemporal distribution of seasonal rainfall [4]. Climate change impacts seasonal and annual rainfall characteristics [5-7], thus impacting the runoff process [8]. River runoff and its seasonal trends directly affect the development and utilization of water resources in different basins. It is extremely important to study the characteristics of runoff changes and understand the behavior of these trends. Studying runoff processes in arid 
and semiarid regions is a challenging task due to the high temporal and spatial variability of rainfall, high evaporation rates, deep groundwater resources, poorly developed soils, and the possibility of a lack of surface runoff [9-12]. Rainfall and runoff generation data are relatively scarce for arid and semiarid regions, despite its importance for environmental and water management. This dearth of data prevents the development of a proper understanding of the rainfall-runoff transformation and the internal watershed processes $[13,14]$.

In many parts of China, a lack of adequate clean water resources has become a major obstacle to the coordinated socioeconomic development of the country and related environmental protection efforts $[15,16]$. Accurate assessment of regional water resources ensures water available and guarantees sustainable socioeconomic development has become an urgent issue in China [17]. The semiarid western area of Heilongjiang Province serves as an important grain production base in China [18]. Rain-based farming serves as the main agricultural type in western Heilongiang Province [19], and drought has become one of the main natural disasters in this typical dry farming region in China [20]. The annual rainfall in the semiarid monsoon climate of the cold temperature zone exhibits an uneven spatiotemporal distribution, with little winter snow, a typically dry spring season, and rainfall concentrated in summer and autumn. These meteorological characteristics are not conducive to agricultural production [21,22]. Clarification of the main seasonal runoff characteristics is helpful for the effective and sustainable utilization of water resources, and it is important for ensuring grain production in the western area of Heilongjiang Province.

The activities of this study were conducted in the Alun River Basin with an aim to reveal the main characteristics of surface runoff in the semiarid western area of Heilongjiang. The Alun River Basin has meteorological, hydrological, and topographical characteristics that are typical of western Heilongjiang. This basin is located in the cold region of northeastern China, which generally experiences snow cover in winter and snowmelt in spring. Snowmelt provides the primary water source for the soil, stream systems, and the water cycle in general [23]. The processes of snow ablation and thawing of soil provide a reliable amount of substantial spring runoff [24-26], which provides important water sources for irrigation and ecological. This spring runoff can be managed through flood control [27]. The rainfall-runoff combined snowmelt calculation of the Alun River Basin for six years (2011-2016) was carried out using a distributed hydrological model developed in a previous study [19]. An analysis of rainfall-runoff and the snowmelt process was carried out based on the numerical results combined with the observed data of rainfall and runoff. The results are expected to provide a basis for the development and rational use of surface water resources in the semiarid western Heilongjiang Province of China.

\section{Materials and Methods}

\subsection{Study Area}

The Alun River Basin $\left(47^{\circ} 37^{\prime}-48^{\circ} 48^{\prime} \mathrm{N}, 122^{\circ} 04^{\prime}-124^{\circ} 4^{\prime}\right.$ E; Figure 1$)$ was chosen as the study location. This basin begins along the southeastern base of the Greater Khingan Mountain Range and stretches through eastern Inner Mongolia and the western Heilongjiang Province of China. The basin covers $6297 \mathrm{~km}^{2}$ with a main river channel length of $318 \mathrm{~km}$. Elevation in the basin ranges from 153-198 m a.s.l. The terrain gradually slopes from northwest to southeast, and the downstream area is located in the western part of the Songnen Plain [28,29]. The Alun River Basin was chosen as the study area because it exhibits diversified landscape types in terms of geology, morphology, soils, hydrology, and climatic conditions, and it also represents several different land use patterns that are typical of the semiarid environment of western Heilongjiang. This basin is located within middle and high latitudes of northeast China with annual mean temperatures of $2.0-2.5^{\circ} \mathrm{C}$. Mean annual rainfall is $455 \mathrm{~mm}$ with highly irregular and uneven seasonal distribution. Over $70 \%$ of the total rainfall is received in a period from June to August [30]. Annual potential evapotranspiration exceeds $1000 \mathrm{~mm}$, which is significantly higher than the annual precipitation [31]. The inadequate and unpredictable rainfall in 
addition to the dominant evapotranspiration often leads to seasonal water scarcity and rainwater deficiency. This is a widespread problem during the vegetation growth period. The ratio of annual rainfall and potential evapotranspiration lies in the range of $0.2-0.5$ making this region part of the semiarid climatic zone [28,32,33].

\subsection{Hydrological Observations}

Hydrological observations mainly included the observation of rainfall, snow depth, and discharge of river flow. Tipping rain gauges [model number: 7852M-L10, dimensions: $\varphi 165 \times 240 \mathrm{H}(\mathrm{mm})$ ] were used for rainfall observations (Site 1: $48^{\circ} 1^{\prime} 30.68^{\prime \prime} \mathrm{N}, 123^{\circ} 34^{\prime} 6.90^{\prime \prime} \mathrm{E}$; Site 2: $48^{\circ} 41^{\prime} 54.36^{\prime \prime} \mathrm{N}$, $\left.123^{\circ} 46^{\prime} 48.32^{\prime \prime} \mathrm{E}\right)$. The flow velocity in the river channel is very slow as the downstream terrain exhibits a gentle slope with a gradient generally lower than $1 / 2000$. The flow discharge was observed on a section near the Naji Hydrological Station $\left(48^{\circ} 5^{\prime} 42.15^{\prime \prime} \mathrm{N}, 123^{\circ} 28^{\prime} 7.44^{\prime \prime}\right.$ E; Figure 1$)$. The catchment area upstream from the flow observation section is $4212 \mathrm{~km}^{2}$, which accounts for $67 \%$ of the total basin area. To estimate the flow in the river channel, water level data were converted into discharge data. Manning's mean velocity formula was applied to the conventional method for data transformation from water level to discharge (Equation (2)) [34]. Daily snow depth was measured via a millimeter scale (Point 1: $48^{\circ} 1^{\prime} 53.73^{\prime \prime} \mathrm{N}, 123^{\circ} 39^{\prime} 17.28^{\prime \prime}$ E; Point 2: $48^{\circ} 1^{\prime} 55.99^{\prime \prime} \mathrm{N}, 123^{\circ} 38^{\prime} 47.73^{\prime \prime} \mathrm{E}$ ). The data for rainfall and snow depth were also provided by the Naji Hydrological Station. Meteorological data including air temperature, solar radiation, wind speed, and atmospheric pressure were obtained from the Xinglong Meteorological Station (Figure 1). Observations of rainfall and snow depth were also collected by this meteorological station.

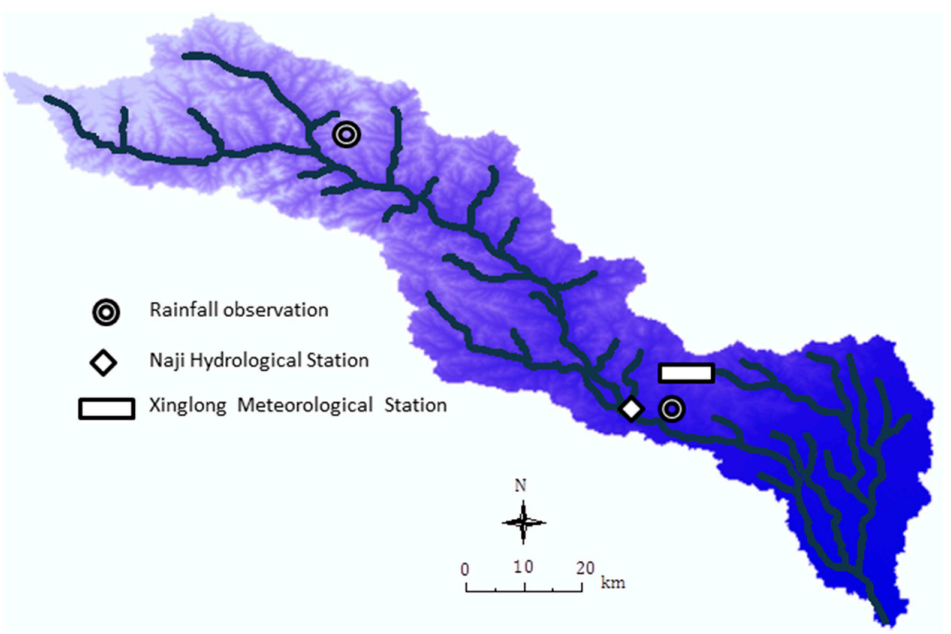

Figure 1. Illustration of hydrological observation field sites, DEM (digital elevation model), and river channel networks of the Alun River Basin.

\subsection{Overview of the Development of a Distributed Hydrological Model}

Estimation of surface runoff using rainfall-runoff models is an important set in the planning and development of limited water resources [35]. Different types of models have conventionally been proposed for rainfall-runoff simulation, such as the widely used models based on artificial neural networks [36,37], the Xinanjiang model of China [38,39], the GIS-based kinematic wave model [40,41], and stationary and non-stationary approaches were often used for rainfall and flood analysis of climate change [42,43]. Each model has its own characteristics and advantages. GIS has been widely deployed in combination with the kinematic wave model for rainfall-runoff modeling of basins at various scales. The kinematic wave model is based on the resistance law of river channels. It is a physically-based model, as it uses physical parameters to characterize a basin [40,44]. In a previous study, a GIS-based distributed hydrological rainfall-runoff model was combined with snowmelt data to simulate the Alun 
River Basin. The model employed the kinematic wave model in combination with the energy budget method. The model was then fully validated [19].

\subsubsection{Equations for Runoff Calculation}

Equations (1)-(3) were used to calculate surface flow:

$$
\begin{gathered}
\frac{\partial h}{\partial t}+\frac{\partial q}{\partial x}=r-f_{1}, \\
v=\frac{1}{n} R^{2 / 3} I^{1 / 2}, \\
q=\alpha h^{m}, \\
\alpha=\frac{\sqrt{I}}{n}, m=\frac{5}{3},
\end{gathered}
$$

where, $t$ is the time factor, $(\mathrm{s}) ; x$ is the spatial factor in the flow direction, $(\mathrm{m}) ; h$ is the depth of water, $(\mathrm{m}) ; q$ is discharge of unit width, $\left(\mathrm{m}^{2} / \mathrm{s}\right) ; r$ is the effective rainfall, $(\mathrm{m} / \mathrm{s}) ; f_{1}$ is mean infiltration rate of the first soil layer, $(\mathrm{m} / \mathrm{s}) ; v$ is flow velocity, $(\mathrm{m} / \mathrm{s}) ; R$ is hydraulic radius, $(\mathrm{m}) ; n$ is coefficient of roughness, $\left(\mathrm{s} \cdot \mathrm{m}^{-1 / 3}\right) ; I$ is gradient; and $\alpha$ and $m$ are the slope constants. The value of $m$ is $5 / 3$ when $R$ is approximately replaced by $h$.

Equations (5)-(7) were used to calculate infiltration flow:

$$
\begin{aligned}
\lambda \frac{\partial \bar{h}}{\partial t}+\frac{\partial \bar{q}}{\partial x} & =f_{1}-f_{2}-E T, \\
\bar{v} & =k \frac{d \bar{H}}{d x}, \\
\bar{q} & =\bar{v} \cdot \bar{h},
\end{aligned}
$$

where, $\lambda$ is effective porosity; $\bar{h}$ is depth of infiltration flow, $(\mathrm{m}) ; \bar{q}$ is discharge of unit width of infiltration flow, $\left(\mathrm{m}^{2} / \mathrm{s}\right) ; f_{2}$ is mean infiltration rate of the second soil layer, $(\mathrm{m} / \mathrm{s})$; ET is evapotranspiration, $(\mathrm{m} / \mathrm{s}) ; \bar{v}$ is velocity of infiltration flow, $(\mathrm{m} / \mathrm{s}) ; k$ is coefficient of permeability, $(\mathrm{m} / \mathrm{s})$; $\bar{H}$ is hydraulic head of the infiltration flow, $(\mathrm{m})$; and other factors correspond to those mentioned above.

Calculation of surface flow and infiltration flow algorithms was established by using Equations (1)-(7) in combination with the finite difference method [19].

\subsubsection{Equations for Snowmelt Calculation}

Snowmelt calculation was achieved by calculating the heat budget process in the snow cover layer using Equations (8)-(10) [45,46]:

$$
\begin{gathered}
Q_{g}=R-\varepsilon \sigma T_{s}^{4}-H-l E+Q_{b}+Q_{r} \\
R=(1-r e f) S+\varepsilon L \\
L=\sigma T^{4}
\end{gathered}
$$

where, $Q_{\mathrm{g}}$ is the snowmelt heat obtained from the surface and bottom of the snow cover layer $\left(\mathrm{W} / \mathrm{m}^{2}\right)$; $R$ is incident radiation $\left(\mathrm{W} / \mathrm{m}^{2}\right) ; \varepsilon$ is the emissivity of snow cover layer; $\sigma$ is the Stefan-Boltzman constant $\left(5.67 \times 10^{-8} \mathrm{~W} /\left(\mathrm{m}^{2} \cdot \mathrm{K}^{4}\right)\right) ; T_{\mathrm{s}}$ is the surface temperature of the snow cover layer $(\mathrm{K}) ; H$ is the sensible heat flux $\left(\mathrm{W} / \mathrm{m}^{2}\right) ; l E$ is the latent heat flux $\left(\mathrm{W} / \mathrm{m}^{2}\right) ; Q_{\mathrm{b}}$ is the heat exchange between the bottom of the snow cover layer and the soil $\left(\mathrm{W} / \mathrm{m}^{2}\right) ; Q_{\mathrm{r}}$ is the heat contained in rain $\left(\mathrm{W} / \mathrm{m}^{2}\right) ; S$ is the horizontal solar radiation $\left(\mathrm{W} / \mathrm{m}^{2}\right) ; L$ is the downward atmospheric radiation $\left(\mathrm{W} / \mathrm{m}^{2}\right)$; ref is the albedo of the snow cover surface; and $T$ is the air temperature $(\mathrm{K})$. 
Estimation of the sensible heat flux and the latent heat flux was dependent on meteorological data:

$$
\begin{gathered}
H=c_{p} \rho C_{H} U\left(T_{S}-T\right), \\
l E=l \rho C_{E} U\left[(1-r h) q_{s a t}(T)+\Delta \cdot\left(T_{S}-T\right)\right],
\end{gathered}
$$

where, $c_{\mathrm{p}}$ is specific heat of air at constant pressure, $(\mathrm{J} /(\mathrm{kg} \cdot \mathrm{K})) ; \rho$ is air density, $\left(\mathrm{kg} / \mathrm{m}^{3}\right) ; C_{\mathrm{H}}$ and $C_{\mathrm{E}}$ represent the bulk coefficient corresponding to sensible heat and latent heat, respectively; $U$ is wind speed, $(\mathrm{m} / \mathrm{s}) ; l$ is latent heat of vaporization, $(\mathrm{J} / \mathrm{kg}) ; q_{\mathrm{sat}}(T)$ represents the saturation specific humidity corresponding to air temperature; $\Delta$ is slope of the saturation vapor-pressure at air temperature; $r h$ is relative humidity; and the other factors correspond to those of above mentioned.

Snow depth and snow density varied due to temporal changes and compaction of the snow cover layer even within the same snowpack. The density of snow cover could only be considered as uniform. The mean snow density in the snowmelt calculation processes was generated by using Equations (13)-(16):

$$
\begin{gathered}
d D=\beta_{N} R_{S}\left(\frac{D}{10}\right)^{0.24} \frac{\rho_{w}}{\rho_{D}}, \\
\rho_{D}=\rho_{w} \frac{S}{D^{\prime}}+\beta^{\prime}\left(\rho_{\max }-\rho_{D}^{\prime}\right), \\
D=D^{\prime}-d D+D_{n}, \\
D_{n}=R_{S} \frac{\rho_{w}}{\rho_{s}},
\end{gathered}
$$

where, $d D$ is the compression height of snowpack, $(\mathrm{m})$; $D$ is snow depth before snowfall, $(\mathrm{m}) ; \beta_{\mathrm{N}}$ is the compression coefficient of new snow; $\rho_{\mathrm{w}}$ is water density, $\left(\mathrm{kg} / \mathrm{m}^{3}\right) ; \rho_{\mathrm{D}}$ is density of the snow cover layer, $\left(\mathrm{kg} / \mathrm{m}^{3}\right) ; S$ is water depth in the snow cover layer $(\mathrm{m}) ; \rho_{D}^{\prime}$ is snow density before calculation, $\left(\mathrm{kg} / \mathrm{m}^{3}\right) ; \rho_{\max }$ is the maximum density of snow cover layer, $\left(\mathrm{kg} / \mathrm{m}^{3}\right) ; \beta^{\prime}$ is the compaction velocity of snow cover; $D_{\mathrm{n}}$ is snow depth of new snowfall, $(\mathrm{m}) ; R_{\mathrm{s}}$ is snowfall, $(\mathrm{m}) ; \rho_{\mathrm{s}}$ is density of new snow, $\left(\mathrm{kg} / \mathrm{m}^{3}\right)$; and other factors correspond to those mentioned above.

\subsubsection{Definite Conditions}

The same conditions for the rainfall-runoff calculation were adopted for the initial condition and boundary condition. The discharges of the surface and infiltration flow in the flow direction were assumed as 0 at the end of the upstream area (the origin of the flow) in each distributed basin (Figure 2).

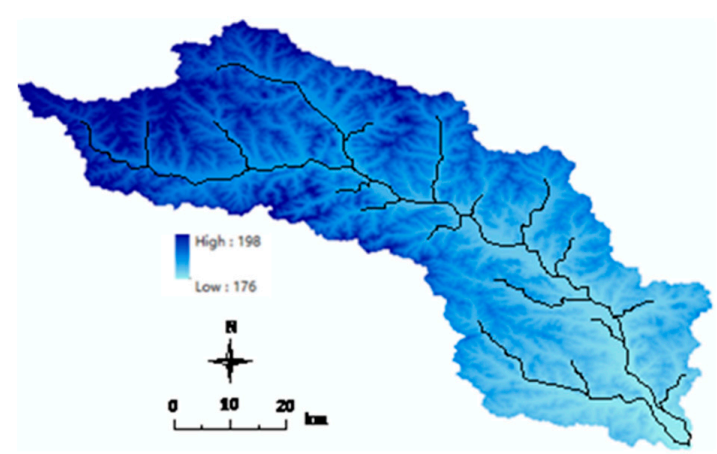

(a)

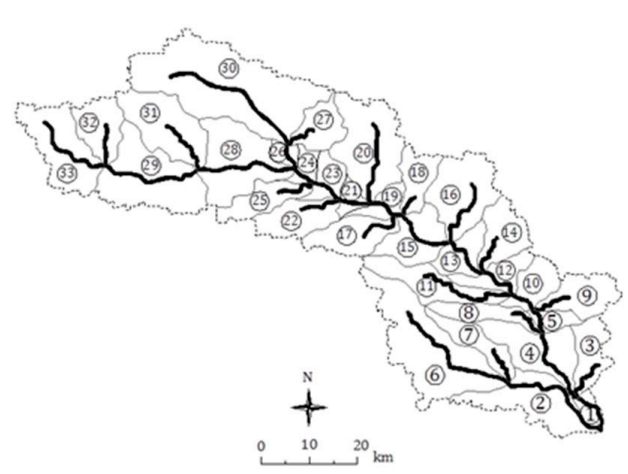

(b)

Figure 2. (a) DEM and river channel networks, and (b) spatial connection relationship of the sub-catchments for the catchment area of the Naji Hydrological Section (catchment area: $4212 \mathrm{~km}^{2}$ ). 


\subsubsection{Model Parameters}

The parameters of the model were determined by field surveys, experiments, and a digital elevation model (DEM; Figures 1 and 2a) of the Alun River Basin. For example, the gradients of slopes and river channel were mainly obtained via the DEM. Some parameters related to the soil hydraulic properties, such as infiltration velocity and soil porosity, were determined by infiltration experiments at different sites within the Alun River Basin. Directly determining some parameters, such as infiltration velocity, coefficient of permeability, and soil porosity of the subsequent soil layer (below the topsoil), proved difficult despite the use of field surveys, experiments, and a DEM. The process for calibrating such parameters is as follows. Initially, each undetermined parameter was assigned a relatively rational initial value. Next, a massive number of model calculations were conducted, and data were compared with the observed flow discharge. After the calculations were performed, errors were filtered. Finally, the parameters that produced the smallest amount of error were chosen for the numerical calculations. A loss coefficient was adopted to approximately evaluate evapotranspiration (including loss of rainfall) in the process of the rainfall-runoff calculations. Table 1 shows the characteristic values of the main parameters, and each parameter is expressed in the corresponding order of magnitude.

Table 1. Index of the main parameters for the rainfall-runoff calculation.

\begin{tabular}{|c|c|c|c|c|}
\hline \multirow{2}{*}{ Parameters } & \multicolumn{2}{|r|}{ Slope } & \multirow{2}{*}{ River Channel } & \multirow{2}{*}{ Unit } \\
\hline & The Topsoil Layer & The Subsequent Soil Layer & & \\
\hline Coefficient of roughness $/ n$ & 0.08 & & 0.06 & $\mathrm{~s} \cdot \mathrm{m}^{-1 / 3}$ \\
\hline Coefficient of permeability $/ k$ & $1.0 \times 10^{-5}$ & $2.5 \times 10^{-6}$ & $4.0 \times 10^{-6}$ & $\mathrm{~m} \cdot \mathrm{s}^{-1}$ \\
\hline Vertical infiltration velocity/f & $3.0 \times 10^{-6}$ & $4.0 \times 10^{-7}$ & $4.5 \times 10^{-7}$ & $\mathrm{~m} \cdot \mathrm{s}^{-1}$ \\
\hline Thickness of soil layer $/ H_{S}$ & 5 & 20.0 & 20.0 & $\mathrm{~m}$ \\
\hline Depth of water $/ h$ & 2.0 & & & $\mathrm{~m}$ \\
\hline Soil porosity $/ \lambda$ & 0.35 & 0.20 & 0.20 & \\
\hline Loss coefficient/los & & $a \times 10^{-8}$ & & $\mathrm{~m} \cdot \mathrm{s}^{-1}$ \\
\hline
\end{tabular}

In Table 1, different values of $a$ were adopted for the rainfall-runoff calculation for six years (2011-2016). The related content is mentioned in Section 3.2.5-Analysis of decreasing trend of annual peak and annual runoff.

\subsubsection{Model Applicability}

Model validation was accomplished via simulation of the observed runoff process in addition to subsequent correlation tests and error analysis. Simulated and observed runoff results of the six years (2011-2016) for the Naji Hydrological Section (Figure 2) are illustrated in Figure 3. Figure 3 represents the simulated results that appropriately reproduced the observed runoff. The numerical results exhibit an excellent fit with the observed data despite the fact that the observed flow data set exhibited gaps during some periods. The simulation results for rainfall-runoff combined with snowmelt exhibit an error less than 0.03 and a Nash-Sutcliffe efficiency (NSE) that exceeded 0.90 [19]. This indicates that this model has relatively high calculation accuracy and a high efficiency. This model was therefore sufficient to adequately calculate rainfall-runoff combined with snowmelt in the Alun River Basin. 


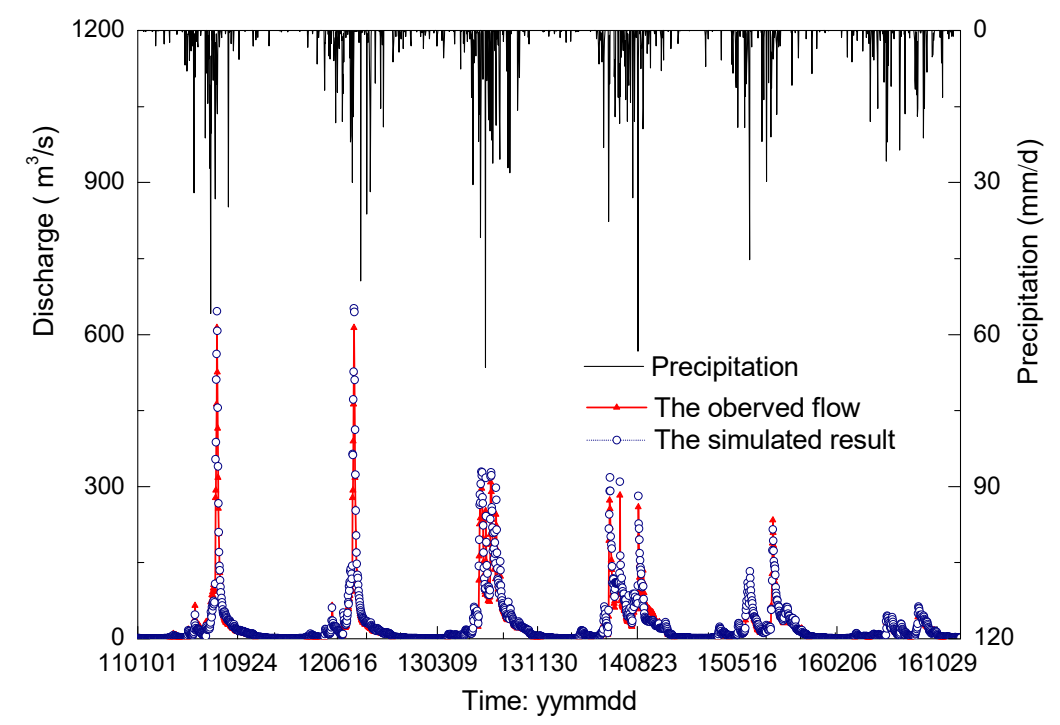

Figure 3. Hydrograph of rainfall-runoff simulated result at the Naji Hydrological Section (1 January, 2011-31 December, 2016).

\section{Results and Discussion}

\subsection{Rainfall-Runoff Calculation}

Figure 4 shows the spatial connection of the river channel networks within the whole region of the Alun River Basin. Rainfall-runoff calculation of the six years (2011-2016) for the Alun River Basin region was performed. The rainfall-runoff results of the whole region (the outlet section of the Alun River Basin) and the Naji Hydrological Section are shown in Figure 5. Figure 5 exhibits a similar temporal runoff process in the two sections. As the area of the Alun River Basin is larger than the catchment of the Naji Hydrological Section, the peak flows of the basin outlet section are higher than that of the Naji Hydrological Section at the corresponding time. No obvious difference exists between the base-flows of the two sections except during the annual rainy season (June to September), while the peak flow exhibits a decreasing trend from 2012-2016.

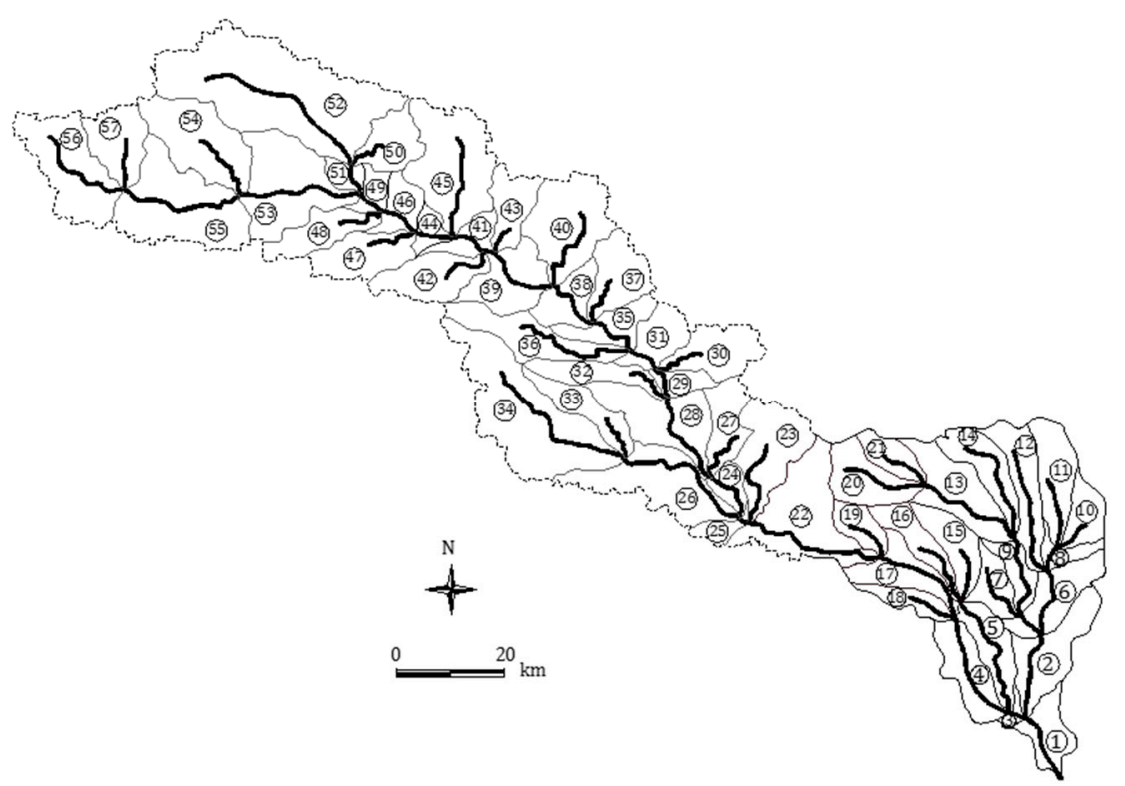

Figure 4. Spatial connection relationship of sub-catchments for the Alun River Basin (Area: $6297 \mathrm{~km}^{2}$ ). 


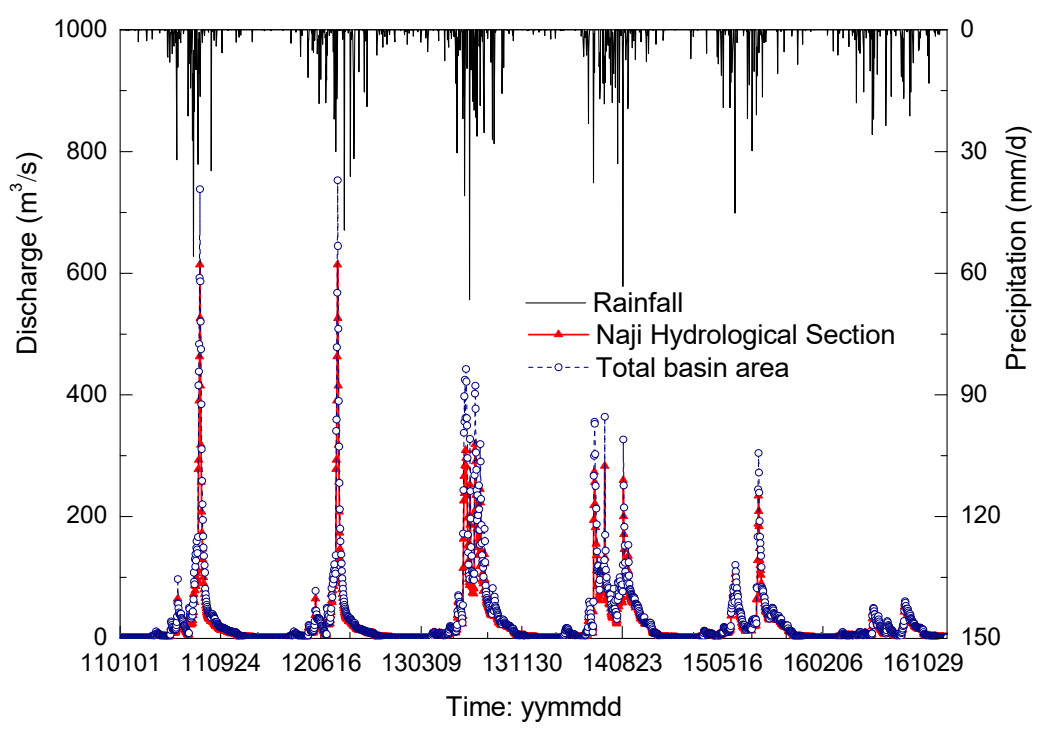

Figure 5. Hydrograph of rainfall-runoff simulated results of the Naji Hydrological Section and the outlet section of the Alun River Basin (1 January, 2011-31 December, 2016).

\subsection{Analysis and Discussion}

\subsubsection{Relationship between Flow Discharge and Catchment Area}

To evaluate the relationship between the flow discharge and the catchment area, flow discharges caused by 20 of the intensive rainfall events were randomly selected for the Naji Hydrological Section and the outlet section of the Alun River Basin. The results are exhibited in Figure 6 and Table 2 . Flow discharge of the outlet section was generally greater than that of the Naji Hydrological Section for a given time since the former catchment area $\left(6297 \mathrm{~km}^{2}\right)$ is larger that of the latter $\left(4212 \mathrm{~km}^{2}\right)$. The mean of the 20 flow discharges and the maximum discharge were 199 and $614 \mathrm{~m}^{3} / \mathrm{s}$ for the Naji Hydrological Section, respectively, while they were 264 and $790 \mathrm{~m}^{3} / \mathrm{s}$ for the outlet section. The mean and the maximum discharges of the Naji Hydrological Section are equivalent to $75 \%$ and $78 \%$ of that of the outlet section, respectively. The catchment area of the Naji Hydrological Section accounts for $67 \%$ of the total basin area, while the mean and the maximum of the 20 flow discharges accounted for more than $70 \%$ of value for the whole basin. These results indicate that although the increase of flow discharge is not proportional to the increase of the catchment area, runoff of the Naji Hydrological Section can relatively fully represent the runoff characteristics in the Alun River Basin.

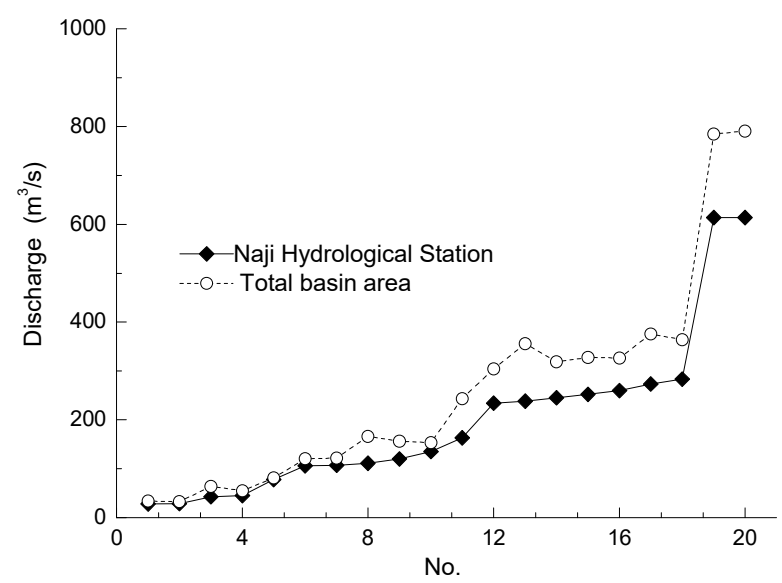

Figure 6. Comparison of the 20 discharges between the Naji Hydrological Section and the whole basin. 
Table 2. Comparison of flow discharge and catchment area.

\begin{tabular}{ccccccc}
\hline Section Location & $\begin{array}{c}\text { Catchment } \\
\text { Area/ } / \mathbf{k m}^{2}\end{array}$ & $\begin{array}{c}\text { Mean of the 20 Flow } \\
\text { Discharges } / \mathbf{m}^{3} / \mathbf{s}\end{array}$ & $\begin{array}{c}\text { Maximum } \\
\text { Discharge/ } \mathbf{m}^{3} / \mathbf{s}\end{array}$ & $\begin{array}{c}\text { Areal } \\
\text { Ratio/\% }\end{array}$ & $\begin{array}{c}\text { Ratio of Mean } \\
\text { Discharge } \%\end{array}$ & $\begin{array}{c}\text { Ratio of the Maximum } \\
\text { Discharge/\% }\end{array}$ \\
\hline Naji Hydrological & 4212 & 199 & 614 & 67 & 75 & 78 \\
$\begin{array}{c}\text { Section } \\
\text { Basin outlet section }\end{array}$ & 6297 & 264 & 790 & 100 & 100 & 100 \\
\hline
\end{tabular}

\subsubsection{Annual Runoff Coefficient}

The annual runoff coefficient of the six years (2011-2016) at the Naji Hydrological Section and over the whole basin were estimated by analyzing the rainfall-runoff numerical results of the Naji Hydrological Section and the outlet section (Figure 5). These numerical results were combined with the observed runoff at the Naji Hydrological Section (Figure 3), and the results are shown in Table 3. The annual runoff coefficient of the Naji Hydrological Section is very similar to that of the outlet section in each corresponding year. Overall, higher annual precipitation generally led to more annual runoff from 2011-2016. The precipitation in 2013 was the maximum $(650.9 \mathrm{~mm})$ and runoff was the largest $\left(17.0 \times 10^{8} \mathrm{~m}^{3}\right.$ for the outlet section). The runoff coefficient was also the maximum (0.42) in 2013. There was no evident difference between annual runoff coefficients from 2011-2015. The annual runoff coefficients ranged from $0.34-0.47$, with a mean was 0.38 . Although the precipitation in 2016 was slightly higher than that of 2015, the runoff coefficient in 2016 (0.16) was significantly lower than the coefficients in 2015 and the other four years. Runoff in $2016\left(4.2 \times 10^{8} \mathrm{~m}^{3}\right)$ was also obviously lower than that of the other five years. Runoff in 2016 was equivalent to approximately $1 / 3$ of the mean $\left(12.7 \times 10^{8} \mathrm{~m}^{3}\right)$ during $2011-2015$. The mean annual precipitation of the six years (2011-2016) was $511 \mathrm{~mm}$, and the mean annual runoff coefficient was 0.34 . From the view point of the annual hydrological cycle, the annual evapotranspiration exceeds the annual mean precipitation in the semiarid western area of Heilongjiang Province by $60 \%$.

Table 3. Annual precipitation, runoff, and runoff coefficients from 2011-2016.

\begin{tabular}{|c|c|c|c|c|c|c|}
\hline \multirow[b]{2}{*}{ Year } & \multirow{2}{*}{$\begin{array}{c}\text { Annual } \\
\text { Precipitation/mm }\end{array}$} & \multicolumn{2}{|c|}{ Naji Hydrological Section } & \multicolumn{2}{|c|}{ Total Basin Area/Outlet Section } & \multirow{2}{*}{$\begin{array}{c}\text { Mean Runoff } \\
\text { Coefficient }\end{array}$} \\
\hline & & Runoff $/ 10^{8} \mathrm{~m}^{3}$ & $\begin{array}{c}\text { Runoff } \\
\text { Coefficient }\end{array}$ & Runoff $/ 10^{8} \mathrm{~m}^{3}$ & $\begin{array}{c}\text { Runoff } \\
\text { Coefficient }\end{array}$ & \\
\hline 2011 & 490.2 & 7.7 & 0.374 & 11.7 & 0.379 & 0.37 \\
\hline 2012 & 520.5 & 7.7 & 0.352 & 11.5 & 0.350 & 0.35 \\
\hline 2013 & 650.9 & 11.8 & 0.429 & 17.0 & 0.415 & 0.42 \\
\hline 2014 & 580 & 10.3 & 0.422 & 15.0 & 0.409 & 0.41 \\
\hline 2015 & 410 & 6.3 & 0.366 & 8.5 & 0.327 & 0.34 \\
\hline 2016 & 417.2 & 2.9 & 0.164 & 4.2 & 0.160 & 0.16 \\
\hline
\end{tabular}

\subsubsection{Monthly Runoff Distribution}

The catchment area of the Naji Hydrological Section (Figure 3) accounts for 67\% of the total basin area of the Alun River Basin. Therefore, runoff characteristics of this catchment can be considered as adequately representing runoff characteristics of the whole basin. Monthly rainfall and estimation of monthly runoff during the six years (2011-2016) in the Naji Hydrological Section are shown in Figure 7. The figure illustrates that annual precipitation and runoff are mainly concentrated in the rainy season from June to September. The statistical results of annual rainfall and runoff in June to September of 2011-2016 are listed in Table 4. The mean monthly rainfall in the rainy season (June to September) accounted for $20 \%, 27 \%, 18 \%$, and $13 \%$ of annual mean precipitation, while monthly runoff in this period accounted for $14 \%, 30 \%, 28 \%$, and $12 \%$ of annual mean runoff in 2011-2016. Rainfall and runoff in each month of the rainy season exceeded annual precipitation and runoff in 2011-2016 by at least $10 \%$. In July, the mean rainfall and runoff reach maxima. The mean rainfall reached $140 \mathrm{~mm}$ and runoff was $2.34 \times 10^{8} \mathrm{~m}^{3}$, respectively. This accounted for $27 \%$ and $30 \%$ of the mean annual precipitation and mean annual runoff of 2011-2016, respectively. 


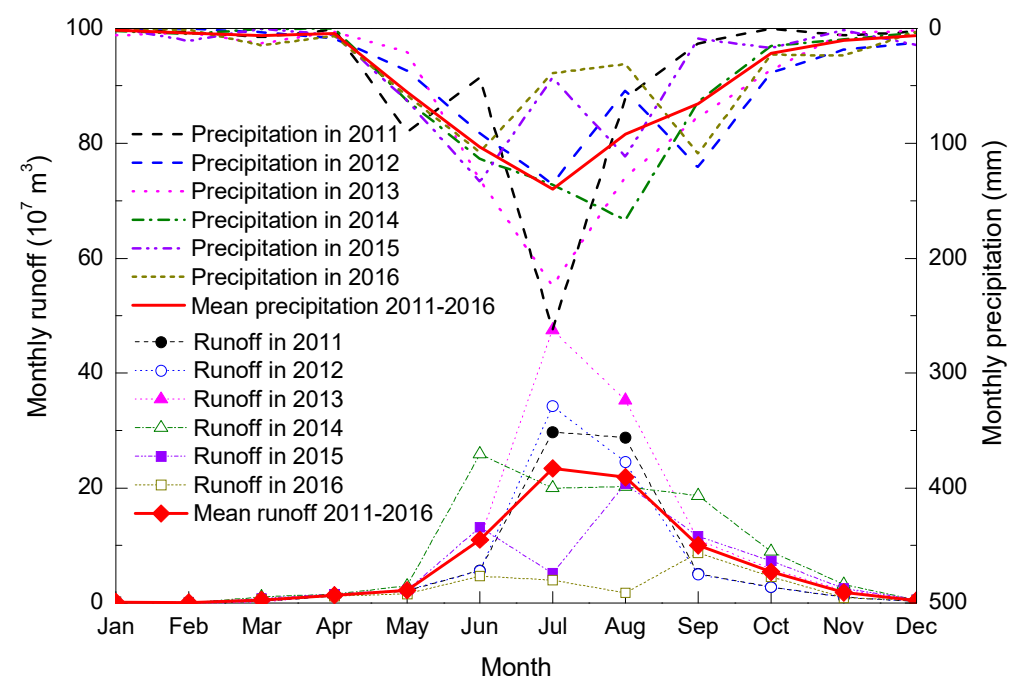

Figure 7. Distributions of monthly runoff and monthly precipitation of the Naji Hydrological Section (2011-2016).

Table 4. Statistics regarding rainfall and runoff coefficient during the rainy season from June to September (2011-2016) in the Alun River Basin.

\begin{tabular}{cccccccc}
\hline Year & $\mathbf{2 0 1 1}$ & $\mathbf{2 0 1 2}$ & $\mathbf{2 0 1 3}$ & $\mathbf{2 0 1 4}$ & $\mathbf{2 0 1 5}$ & $\mathbf{2 0 1 6}$ & Mean \\
\hline Rainfall/mm & 377.8 & 401 & 562.3 & 480.4 & 297.2 & 286.5 & 400.9 \\
Ratio of annual precipitation $/ \%$ & 77 & 77 & 86 & 83 & 72 & 69 & 78 \\
Runoff $/\left(10^{8} \mathrm{~m}^{3}\right)$ & 6.9 & 6.9 & 10.5 & 8.5 & 5.1 & 1.9 & 6.6 \\
Ratio of annual runoff $/ \%$ & 90 & 90 & 89 & 82 & 77 & 67 & 85 \\
Runoff coefficient & 0.44 & 0.41 & 0.44 & 0.42 & 0.40 & 0.16 & 0.39 \\
\hline
\end{tabular}

Rainfall in the rainy season (June to September) exceeded $70 \%$ of annual total precipitation in 2011-2015, while rainfall in the same period accounted for $69 \%$ of the total precipitation in 2016 . The runoff coefficients in the rainy season (June to September) of 2011-2015 attained or exceeded 0.40, while it was only 0.16 in 2016. This result illustrates that the proportion of rainfall that occurred during the rainy season versus the annual precipitation in 2016 was approximate to that found during the other five years (2011-2015), while the ratio of runoff in the rainy season to annual runoff in 2016 was significantly lower than that of 2011-2015.

Runoff in the rainy season in 2011 and 2012 reached $90 \%$ of the annual total runoff, while it exceeded 80\% in 2013 and 2014. In 2015 and 2016, the proportions of runoff in the same period (June to September) to annual totals were still approximately $70 \%$. The mean runoff coefficient was 0.39 during the rainy season (June to September) of 2011-2016.

The mean precipitation and runoff in the rainy season from June to September accounted for $78 \%$ and $84 \%$ of the annual means, respectively, during 2011-2016. This means that precipitation and runoff in the other months (except June to September) only contributed $22 \%$ and $16 \%$ to annual precipitation and annual runoff, respectively. The freezing period in the Allen River Basin is from late November to March of the next year. According to the field survey, the main river channel was not cut off during the freezing period, as the base flow exists below the ice layer. However, the discharge was very small, with a size of $0.5-1.5 \mathrm{~m}^{3} / \mathrm{s}$. Monthly precipitation and runoff in January, February, November, and December were less than $1 \%$ of annual precipitation and annual runoff, respectively, during 2011-2016. These results highlight the characteristics of very uneven distributions of monthly precipitation and runoff in the semiarid western region of Heilongjiang Province. 


\subsubsection{Runoff during the Main Snowmelt Period}

Figure 8 represents the trend in mean snow depth and the calculated discharge for the Naji Hydrological Section during the main annual snowmelt period (March 1 to April 15) from 2011-2016. During the annual main snowmelt period, the snowmelt process was similar despite the fact that snow depth differed between each year. The depth of snow cover began to decrease gradually at the beginning of March, and flow discharge slowly increased, but this increase was nonobvious before late March. The concentrated snowmelt period is from late March to early April. The flow discharge significantly increases from the late March level and attains a peak at the end of March or early April. The flow discharge exhibits a decreasing trend after the peak although the deceasing trend exhibits with slight differences between each year. In 2015, snowfall occurred during the flow decreased period, and the followed snowmelt resulted in flow discharge increased in the following 3 days, and then the flow discharge decreased (Figure 8). No large difference exists between the peak flows in the main snowmelt period during 2011-2016. The peak discharge was approximately $10 \mathrm{~m}^{3} / \mathrm{s}$. The maximum was $10.9 \mathrm{~m}^{3}$ /s (i.e., 2013 and 2015) and the minimum was $9.2 \mathrm{~m}^{3} / \mathrm{s}$ (i.e., 2014). The mean peak of the six years was $10.2 \mathrm{~m}^{3} / \mathrm{s}$. The mean of the discharge in the snowmelt period (March 1 to April 15) varied in each year of 2011-2016. The minimum was $2.7 \mathrm{~m}^{3} / \mathrm{s}$ in 2011 , while the maximum was $4.1 \mathrm{~m}^{3} / \mathrm{s}$ in 2015. The mean discharge for the six years was $3.5 \mathrm{~m}^{3} / \mathrm{s}$.

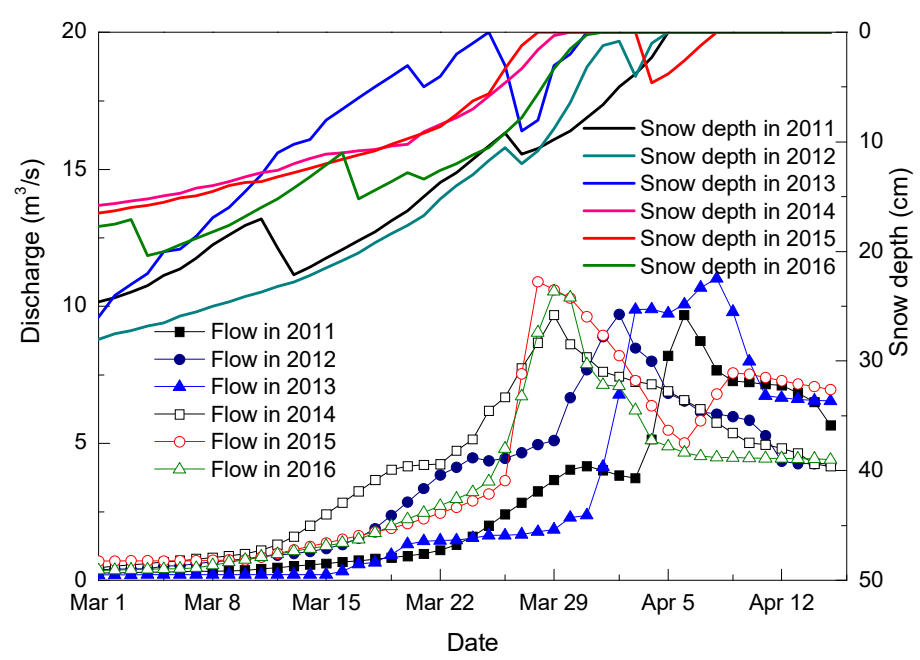

Figure 8. Hydrograph of runoff and snow depth in the main snowmelt period (1 March-15 April) of the Alun River Basin (2011-2016).

Based on the numerical results of snowmelt calculation, runoff levels in the main snowmelt period (March 1 to April 15) were $1.10 \times 10^{7}, 1.45 \times 10^{7}, 1.29 \times 10^{7}, 1.58 \times 10^{7}, 1.66 \times 10^{7}$, and $1.37 \times 10^{7} \mathrm{~m}^{3}$; from 2011-2016, respectively. These levels accounted for $1.4 \%, 1.9 \%, 1.1 \%, 1.5 \%, 2.5 \%$, and $4.7 \%$ of the annual total runoff in each corresponding year. The runoff in the main snowmelt period was $1.37 \times 10^{7} \mathrm{~m}^{3}$ in 2016, which was approximately the mean of that of 2011-2015 $\left(1.42 \times 10^{7} \mathrm{~m}^{3}\right)$. However, runoff during this period in 2016 accounted for $4.7 \%$ of the total runoff in 2016. This was because the total runoff in 2016 was obviously smaller than the mean of the other five years (2011-2015) (Table 3). The mean snowmelt runoff accounted for $2.2 \%$ of annual runoff over the six years (2011-2016).

\subsubsection{Analysis of Decreasing Trend of Annual Peak and Annual Runoff}

Based on rainfall-runoff calculation results of the Naji Hydrological Section and the whole basin combined with the observed data of precipitation in 2011-2016, the peak flow and three-day rainfall before peak flow in each year are given in Table 5 .

Table 5 (combined with Figures 3 and 5) exhibit the peak flows in the six years (2011-2016). They show a decreasing trend on both the Naji Hydrological Section and the outlet section of the Alun 
River Basin. The peak flow was significantly lower than that of the other five years in 2016. Its value was less than a tenth of the levels in 2011 and 2012, and the 2016 level was a fifth of that found in 2015.

Table 5. Statistics for the time, discharge, and rainfall related to peak flow in 2011-2016.

\begin{tabular}{|c|c|c|c|c|c|c|c|}
\hline \multicolumn{2}{|c|}{ Year } & 2011 & 2012 & 2013 & 2014 & 2015 & 2016 \\
\hline \multicolumn{2}{|c|}{ Peak flow occurred time } & 7.31 & 7.30 & 7.30 & 7.08 & 8.19 & 9.11 \\
\hline \multicolumn{2}{|c|}{ Three-day rainfall before the peak / $\mathrm{mm}$} & 29.0 & 25.6 & 28.1 & 30.8 & 17.0 & 15.8 \\
\hline \multirow{2}{*}{ Peak flow $/ \mathrm{m}^{3} \cdot \mathrm{s}^{-1}$} & Naji Hydrological Section & 614 & 614 & 319 & 284 & 234 & 58 \\
\hline & Outlet of the basin & 738 & 753 & 414 & 364 & 304 & 60 \\
\hline
\end{tabular}

Rainfall amount, rainfall intensity, and rainfall duration jointly impact the flow discharge of a catchment [34]. Although three-day rainfall before the peak in 2016 was obviously lower than that found in 2011-2014, it was approximately the same as that in 2015 (Table 1). However, the peak in 2016 was significantly lower than that of 2011-2015. Additionally, there is no proportional relationship between three-day rainfall before the peak and the size of the peak flow. For example, three-day rainfall before the peak in $2014(30.8 \mathrm{~mm})$ was higher than that of 2011 and 2012. However, discharge of the peak in 2014 was notably lower than that of 2011 and 2012.

During the rainy season from June to September of 2011-2016, runoff in 2016 was only $1.9 \times 10^{8} \mathrm{~m}^{3} / \mathrm{s}$. This was obviously lower than that of 2011-2015 (Table 4). Rainfall during this period in 2016 was $286.5 \mathrm{~mm}$, which was approximately of the same as in $2015(297.2 \mathrm{~mm})$. However, runoff was less than half the level in 2015. Compared with 2011-2014, the peak flow in 2015 and 2016 occurred relatively late. Peak flow in 2016 occurred at the end of rainy season.

In the process of the rainfall-runoff simulation, a loss coefficient was adopted to approximately simulate evapotranspiration and loss of rainfall (Table 1). To fit the simulated runoff with observed results, different calibrated values of this loss coefficient within its order of magnitude were adopted in the process of rainfall-runoff calculation for six years (2011-2016), although acceptable simulation results for rainfall-runoff were achieved (Figure 3), however, caused the increases in loss of rainfall and decrease of runoff (Table 4; Figure 3).

A field survey of land use patterns had been conducted within the upstream region of the Alun River Basin during the summer of 2016. In recent years, Heilongjiang Province and Inner Mongolia have enlarged the rice planting area and has converted dry land to paddy land in order to more effectively utilize natural resources [47]. In the upstream area of the Alun River Basin, the agricultural production activities that have converted dry fields to paddy fields have been carried out since 2013. In the spring of 2016, the area of paddy fields evidently increased. Enlarged paddy fields caused the catchment area to decrease. As the main growth period of rice coincides with the local rainy season, paddy fields partially dammed rainwater and runoff. This resulted in notable decreases in peak flows from 2013-2016, and the decreasing trend in annual runoff.

The area of dry fields converted to paddy fields as well as the irrigation levels of paddy fields in the upstream area of the Alun River Basin has not been quantified. Therefore, the impact of paddy fields on runoff exceeds the scope of this study and will require further research.

\section{Concluding Remarks}

The Alun River Basin exhibits typical meteorological and hydrological characteristics of the semiarid western area of Heilongjiang Province and was chosen as the study location. Rainfall-runoff modeling combined with snowmelt numerical calculation was performed for a study period of six years (2011-2016). This was accomplished with a distributed hydrological model that incorporated a rainfall-runoff module and a snowmelt module. Based on the analysis of the combination of rainfall-runoff calculation results and the observed results, some rainfall-runoff characteristics have been achieved as follows: 
The mean annual runoff coefficient was 0.34 for 2011-2016. Annual precipitation and runoff was mainly concentrated in the rainy season from June to September. Rainfall and runoff in this period accounted for $78 \%$ and $85 \%$ of the mean annual total precipitation and annual runoff, respectively.

Annual snowmelt processes were similar year-to-year, and the peak flow in main snowmelt period (March 1 to April 15) was approximately $10 \mathrm{~m}^{3} / \mathrm{s}$. The ratio of the mean annual snowmelt runoff to the mean annual runoff was $2.2 \%$ during 2011-2016.

The peak flow exhibited a decreasing trend. It exceeded $700 \mathrm{~m}^{3}$ in 2011 and 2012, while it was less than $100 \mathrm{~m}^{3}$ in 2016. Low annual precipitation in conjunction with paddy field retention of rainwater and runoff caused the peak flow and runoff to significantly decrease in 2015 and 2016.

The enlarged area of paddy fields that were transformed from dry fields in the upstream region of the Alun River Basin resulted in the evident reduction of annual runoff and the peak flow. This will inevitably impact the downstream agricultural production and the water environment of the Alun River Basin. With climate and environment evolving, the determination of runoff reduction impacts on the water environment and agricultural production will become an increasingly important research topic in the semiarid western area of Heilongjiang Province, China.

Author Contributions: All authors contributed to the design and development of this manuscript. J.H. carried out the rainfall-runoff calculation and prepared the first draft of the manuscript; K.T. as the co-supervisor of J.H. provided many important advices on the concept of methodology and structure of the manuscript, as well as edited the manuscript during revisions; B.W. and J.W. (Jiawei Wen) were responsible for data processing and analysis; J.W. (Jingcai Wang) assisted the model development and validation.

Funding: This research was founded by the National Natural Science Foundation of China (NSFC; 41271046), the Priority Academic Program Development of Jiangsu Higher Education Institutions (PAPD), the Best Talent Project of "Lvyangjinfengjihua" of Yangzhou City (yzlyjfjh2013YB105) of China, the "2018 Young Blue Project" of Yangzhou University, and the Natural Science Foundation of the Jiangsu Higher Education Institutions of China (15KJB170019).

Acknowledgments: Thanks are due to the Naji Hydrological Station $\left(48^{\circ} 5^{\prime} 42.15^{\prime \prime} \mathrm{N}, 123^{\circ} 28^{\prime} 7.44^{\prime \prime} \mathrm{E}\right)$ for providing the partial daily rainfall time series used in this study.

Conflicts of Interest: The authors declare no conflict of interest.

\section{References}

1. Qin, J.; Liu, Y.X.; Chang, Y.P.; Liu, S.W.; Pu, H.Z.; Zhou, J.X. Regional runoff variation and its response to climate change and human activities in Northwest China. Environ. Earth Sci. 2016, 75, 1366. [CrossRef]

2. Dos Santos, J.C.N.; de Andrade, E.M.; Guerreiro, M.J.S.; Medeiros, P.H.A.; de Queiroz Palácio, H.A.; de Araújo Neto, J.R. Effect of dry spells and soil cracking on runoff generation in a semiarid micro watershed under land use change. J. Hydrol. 2016, 541, 1057-1066. [CrossRef]

3. Liu, C.A.; Zhou, L.M.; Jia, J.J.; Wang, L.J.; Si, J.T.; Li, X.; Pan, C.C.; Siddique, K.H.M.; Li, F.M. Maize yield and water balance is affected by nitrogen application in a film-mulching ridge-Furrow system in a semiarid region of China. Eur. J. Agron. 2004, 52, 103-111. [CrossRef]

4. Graef, F.; Haigis, J. Spatial and temporal rainfall variability in the Sahel and its effects on farmers' management strategies. J. Arid Environ. 2001, 48, 221-231. [CrossRef]

5. Acero, F.J.; Parey, S.; García, J.A.; Dacunha-Castelle, D. Return level estimation of extreme rainfall over the Iberian Peninsula: Comparison of methods. Water 2018, 10, 179. [CrossRef]

6. Brunetti, M.; Maugeri, M.; Nanni, T. Changes in total precipitation, rainy days and extreme events in northeastern Italy. Int. J. Climatol. 2001, 21, 861-871. [CrossRef]

7. Ban, N.; Schmidli, J.; Schär, C. Heavy precipitation in a changing climate: Does short-term summer precipitation increase faster? Geophys. Res. Lett. 2015, 42, 2014GL062588. [CrossRef]

8. Lehmann, J.; Coumou, D.; Frieler, K. Increased record-breaking precipitation events under global warming. Clim. Chang. 2015, 132, 501-515. [CrossRef]

9. Wheater, H.; Sorooshian, S.; Sharma, K.D. Hydrological Modeling in Arid and Semi-Arid Areas; Cambridge University: Cambridge, UK, 2008. 
10. Hrachowitz, M.; Bohte, R.; Mul, M.L.; Uhlenbrook, S. On the value of combined event runoff and tracer analysis to improve understanding of catchment functioning in a data-scarce semi-arid area. Hydrol. Earth Syst. Sci. 2011, 15, 2007-2024. [CrossRef]

11. Blöschl, G.; Sivapalan, M.; Wagener, T.; Viglione, A.; Savenije, H. Runoff Prediction in Ungauged Basins; Cambridge University: Cambridge, UK, 2013.

12. Camacho Suarez, V.V.; Saraiva Okello, A.M.L.; Wenninger, J.W.; Uhlenbrook, S. Understanding runoff processes in a semi-arid environment through isotope and hydrochemical hydrograph separations. Hydrol. Earth Syst. Sci. 2015, 19, 4183-4199. [CrossRef]

13. Bracken, L.J.; Croke, J. The concept of hydrological connectivity and its contribution to understanding runoff-dominated geomorphic systems. Hydrol. Process. 2007, 21, 1749-1763. [CrossRef]

14. Dos Santos, J.C.N.; de Andrade, E.M.; Medeiros, P.H.A.; Guerreiro, M.J.S.; de Queiroz Palácio, H.A. Effect of rainfall characteristics on runoff and water erosion for different land uses in a tropical semiarid region. Water Resour. Manag. 2017, 31, 173-185. [CrossRef]

15. Xie, J.Z.; Chen, Z.K. Water resources in China. Acta Geogr. Sin. 1990, 45, 210-219. (In Chinese)

16. Li, Z.F.; Liu, C.M.; Yang, Z.F.; Hao, F.H. Philosophic thoughts on China's water resources. Sci. Technol. Rev. 2002, 9, 39-42. (In Chinese)

17. Duan, C.Q.; Qiu, L.; Huang, Q.; Chen, X.N. Research on quantitative model of water resources carrying capacity in irrigation area (Natural science edition). J. Northwest A F Univ. 2005, 33, 135-138. (In Chinese)

18. Zhao, Y.S.; Wei, Y.X. Infiltration regularity and its simulation in the west semiarid region Heilongjiang Province. J. Irrigation Drain. 2008, 27, 110-112. (In Chinese)

19. Huang, J.B.; Wen, J.W.; Wang, B.; Zhu, S.J. Numerical analysis of the combined rainfall-runoff process and snowmelt for the Alun River Basin, Heilongjiang, China. Environ. Earth Sci. 2015, 74, 6929-6941.

20. Jiang, Q.X.; Fu, Q.; Wang, Z.L. Research on spatial variability of soil water characteristics in western semiarid area of Heilongjiang Province. J. Soil Water Conserv. 2007, 21, 118-122. (In Chinese)

21. Wang, K.Q.; Fu, Q.; Ji, F.; Xu, S.Q. Study on rice water production function and optimization of irrigation schedule of semiarid area of western Heilongjiang Province. Water Sav. Irrig. 2007, 8, 48-51. (In Chinese)

22. Wang, Y.; Chen, L.H.; Yang, Q.H.; Bi, G.Y.; Yu, D.X.; Li, S.S. Transpiration rate of main tree species for farmland shelterbelts in the semiarid region of northeast China. Bull. Soil Water Conserv. 2008, 28, 48-51. (In Chinese)

23. Marks, D.; Domingo, J.; Susong, D.; Link, T.E. A spatially distributed energy balance snowmelt model for application in mountain basins. Hydrol. Process. 1999, 13, 1935-1959. [CrossRef]

24. Bruce, J.P.; Robert, M.H.; James, W.M.; Charles, J.V.; Richard, B.L.; Alexander, I.S.; Igor, A.S.; Stefan, R. Increasing river discharge to the Arctic Ocean. Science 2002, 298, 2171-2173.

25. Zhang, Y.S.; Ohata, T.; Kadota, T. Land-surface hydrological processes in the permafrost region of the eastern Tibetan Plateau. J. Hydrol. 2003, 283, 41-56. [CrossRef]

26. Woo, M.K.; Kane, D.L.; Carey, S.K.; Yang, D. Progress in permafrost hydrology in the new millennium. Permafr. Periglac. Process. 2008, 19, 237-254. [CrossRef]

27. Zhao, L.T.; Gray, D.M. Estimating snowmelt infiltration into frozen soils. Hydrol. Process. 1999, 13, 1827-1842. [CrossRef]

28. Liu, X.Y.; Zhao, L.; Wang, L.G.; Xu, C.Q.; Li, X.Y. Study on erosion resistance of soil in soil and water conservation forest in Alunhe River Basin. Prot. For. Sci. Technol. 2000, 3, 21-23. (In Chinese)

29. Wang, J.C.; Li, L. Discussion on biological treatment project of Meiris Alunhe Basin. Prot. For. Sci. Technol. 2014, 3, 100-101. (In Chinese)

30. Wei, Y.X. Characteristics of Water Transformation and Soil Erosion under Different Tillage Measures in Sloping Farmland of Western Heilongjiang Province. Ph.D. Thesis, Northeast Forestry University, Harbin, China, March 2009. (In Chinese)

31. Wang, J.X.; Zhao, H.C. Ecological benefits of protection forest system of Alunhe River Basin-a tributary of Nenjiang River. Sci. Technol. West China 2011, 34, 41. (In Chinese)

32. Millennium Ecosystem Assessment. Ecosystem and Human Well-Being: Current State and Trends; Islands Press: Washington, DC, USA, 2005.

33. Zhang, Y.F. Water quality condition and variation trend of Alun River of Gannan County and its pollution control Measure. Heilongjiang Environ. J. 2012, 36, 35-37. (In Chinese) 
34. Hinokidani, O.; Huang, J.B.; Yasuda, H.; Kajikawa, Y.; Khumbulani, D.; Li, S.Q. Study on surface runoff characteristics of a small ephemeral catchment in the northern Loess Plateau, China. J. Arid Land Study 2010, 20, 173-177.

35. Ghumman, A.R.; Al-Salamah, I.S.; AlSaleem, S.S.; Haider, H. Evaluating the impact of lower resolutions of digital elevation model on rainfall-runoff modeling for ungauged catchments. Environ. Monit. Assess. 2017, 189, 54. [CrossRef]

36. Wu, C.L.; Chau, K.W.; Li, Y.S. Methods to improve neural network performance in daily flows prediction. J. Hydrol. 2009, 372, 80-93. [CrossRef]

37. Taormina, R.; Chau, K.W. Data-driven input variable selection for rainfall-runoff modeling using binary-coded particle swarm optimization and Extreme Learning Machines. J. Hydrol. 2015, 529, 1617-1632. [CrossRef]

38. Li, Z.J.; Yao, C.; Wang, Z.H. Development and application of grid-based Xinanjiang Model. J. Hohai Univ. (Nat. Sci.) 2007, 35, 131-134. (In Chinese)

39. Li, Z.J.; Yao, C.; Zhang, Y.X.; Xu, Q.; Huang, Y.C. Study on grid-based Xinanjiang model. J. Hydroelectr. Eng. 2009, 28, 25-34. (In Chinese)

40. Yomoto, A.; Islam, M.N. Kinematic analysis of flood runoff for a small-scale upland field. J. Hydrol. 1992, 137, 311-326. [CrossRef]

41. Tanaka, G. Stochastic response characteristics of kinematic wave model. Annu. J. Hydraul. Eng. JSCE 2003, 47, 229-234. [CrossRef]

42. De Luca, D.L.; Galasso, L. Stationary and non-stationary frameworks for extreme rainfall time series in southern Italy. Water 2018, 10, 1477. [CrossRef]

43. Machado, M.J.; Botero, B.A.; Lopez, J.; Frances, F.; Diez-Herrero, A. Flood frequency analysis of historical flood data under stationary and non-stationary modelling. Hydrol. Earth Syst. Sci. 2015, 19, 2561-2576. [CrossRef]

44. Tanaka, G.; Fujita, M.; Kudo, M. Comparison between the kinematic wave model and the storage routing function runoff model-frequency characteristic and stochastic characteristic. J. Hydraul. Coast. Environ. Eng. 1999, 614, 21-36.

45. Ohara, N.; Kavvas, M.L. Field observations and numerical model experiments for the snowmelt process at a field site. Adv. Water Resour. 2006, 29, 194-211. [CrossRef]

46. Herrero, J.; Polo, M.J.; Moñino, A.; Losada, M.A. An energy balance snowmelt model in a Mediterranean site. J. Hydrol. 2009, 371, 98-107. [CrossRef]

47. Meng, T.T. Research on Effects of Paddy Fields Transformed from Dry Fields on Water Environment and Its Control Countermeasures in Jiangchuan Irrigation Area. Master's Thesis, Harbin Institute of Technology, Harbin, China, June 2014. (In Chinese)

(C) 2019 by the authors. Licensee MDPI, Basel, Switzerland. This article is an open access article distributed under the terms and conditions of the Creative Commons Attribution (CC BY) license (http://creativecommons.org/licenses/by/4.0/). 